\title{
PERTANGGUNGJAWABAN PIDANA ATAS PENYALAHGUNAAN PEMBAYARAN BEA PEROLEHAN HAK ATAS TANAH DAN BANGUNAN (BPHTB) OLEH PEJABAT PEMBUAT AKTA TANAH (PPAT)
}

\author{
Intifada Atin Nisya' \\ intifada.anisya@gmail.com \\ Universitas Airlangga
}

\begin{abstract}
This journal is entitled as Criminal Liability for Misappropriation Payments for the Acquisition of Land and Building Rights (BPHTB) by Official Certifier of Title Deeds (PPAT). Normative juridical legal research was applied in this study. The approach used in this problem is the legal approach (statute approach), case approach (case approach), and conceptual approach (conceptual approach).

The background study of this thesis is about the problem for the notary as the Official Certifier of Title Deeds / Land Deed Official (PPAT) who is involved in a criminal act. There are several cases of tax evasion and also fictitious tax invoices. One of the cases in this case is the PPAT in Semarang, which ended is subject to criminal acts of Corruption. It was proved by the tax payment money when he should have paid the tax but not paid and she did some data manipulation to enrich himself. In order to establish an action as a violation against the law, the loss of state finances or just against the law has an item belonging to another person in his power, where the goods are not from the proceeds of crime. Based on this background, there are two main issues, namely How does the Ratio Decide in court decisions related to cases of misuse of BPHTB payments made by PPAT and What is the validity of the sale and purchase deed if BPHTB tax invoice and PPh (final) falsified?
\end{abstract}

Keywords: The Acquisition of Land and Building Rights, Official Certifier of Title Deeds / Land Deed Official, Crime of Evasion, Corruption Crime.

\begin{abstract}
Abstrak
Artikel ini berjudul Pertanggungjawaban Pidana Atas Penyalahgunaan Pembayaran Bea Perolehan HakAtas Tanah Dan Bangunan (BPHTB) OlehPejabat Pembuat Akta Tanah (PPAT). Tipe penelitian yang digunakan yaitu penelitian hukum yuridis normatif. Pendekatan masalah yang digunakan dalam penulisan ini adalah pendekatan perundang-undangan (statute approach), pendekatan kasus (case approach), dan pendekatan konseptual (conceptual approach). Latar belakang penulisan tesis ini yaitu mengenai permasalahan bagi notaris selaku Pejabat Pembuat Akta Tanah (PPAT) yang terlibat dalam suatu perbuatan tindak pidana. Terdapat beberapa kasus mengenai penggelapan pajak dan juga faktur pajak fiktif. Salah satu kasusnya terdapat pada kasus PPAT di Semarang yang dikenai tindak pidana Korupsi. Bahwa uang setoran pajak yang seharusnya terdakwa bayarkan ke kas negara tidak dibayarkan dan melakukan beberapa manipulasi data untuk memperkaya diri sendiri.Untuk menetapkan sebuah tindakan sebagai pelanggaran melawan hukum yang menyebabkan kerugian keuangan negara atau hanya melawan hukum memiliki suatu barang milik orang lain yang berada dalam kekuasaannya dimana barang tersebut bukan dari hasil kejahatan. Berdasarkan latar belakang tersebut, terdapat 2 (dua) pokok permasalahan, yaitu bagaimana Ratio Decidendi putusan pengadilan terkait dengan perkara penyalahgunaan pembayaran BPHTB yang dilakukan oleh PPAT dan Bagaimanakah keabsahan akta jual beli apabila faktur pajak BPHTB dan PPh (final) dipalsukan?
\end{abstract}

Kata Kunci : $\quad$ Bea Perolehan Hak Atas Tanah dan Bangunan, Pejabat Pembuat Akta Tanah, Tindak Pidana Penggelapan, Tindak Pidana Korupsi. 


\section{A. PENDAHULUAN}

\section{Latar Belakang}

Pajak merupakan salah satu komponen penting dalam pembangunan di Indonesia karena sektor pajak di Indonesia merupakan sumber pendapatan terbesar bagi negara. Karena itulah pajak berperan penting bagi pelaksanaan pembangunan nasional. Tanpa ada masyarakat, tidak mungkin ada suatu pajak. ${ }^{1}$ Salah satu sumber potensi pajak yang patut digali sesuai situasi dan kondisi perekonomian serta perkembangan pembangunan bangsa sekarang ini adalah Bea Perolehan Hak Atas Tanah dan Bangunan (selanjutnya disebut BPHTB). ${ }^{2}$ Perolehan hak atas tanah dan bangunan terjadi karena adanya peralihan hak yang meliputi peristiwa hukum dan perbuatan hukum yang terjadi antara orang atau badan hukum oleh Undang-Undang atau peraturan hukum yang berlaku diberi kewenangan untuk memiliki hak atas tanah dan bangunan. ${ }^{3}$ Terhadap pembelian atas tanah maka ada pajak yang harus dibayarkan oleh para pihak, penjual tanah dalam hal ini akan dikenakan pajak penghasilan dan pembeli akan dikenakan BPHTB. BPHTB merupakan salah satu jenis pajak obyektif atau pajak kebendaan dimana pajak terutang didasarkan pertama-tama pada apa yang menjadi obyek pajak baru kemudian memperhatikan siapa yang menjadi subjek pajak. BPHTB adalah pajak yang dikenakan atas perolehan hak atas tanah atau bangunan.

Terhadap pembayaran BPHTB PPAT memiliki peran yang penting. Hal ini dikarenakan terhadap pemungutan pajak terdapat tiga sistem atau cara yang dipergunakan untuk menentukan siapa yang menghitung dan menetapkan jumlah pajak yang terutang oleh seseorang yaitu sistem pemungutan pajak Official assessment system, Self assessment system, dan With holding system. ${ }^{4}$ Indonesia pada prinsipnya menganut self assessment. Tapi model pemungutan pajak yang berlaku di Indonesia tidak mutlak self assessment. Hakekat sistem self assesment dalam pemungutan pajak khususnya pada BPHTB meletakkan wajib pajak sebagai pihak yang aktif dalam melaksanakan kewajiban hlm. 1.

${ }^{1}$ Rochmat Soemitro, Asas dan Dasar Perpajakan I, Edisi revisi, Refika Aditama, Bandung, 2004,

2 Marihot Pahala Siahaan, Bea Perolehan Hak Atas Tanah dan Bangunan Teori dan Praktek, PT. Raja Grafindo, Jakarta, 2003, hlm. 6. hlm. 90 .

${ }^{3}$ Wirawan B. Ilyas, dan Ricard Burton, Hukum Pajak, Edisi Revisi, Salemba Empat, Jakarta, 2004,

${ }^{4}$ http://www.akuntansilengkap.com/pajak/3-sistem-pemungutan-pajak-lengkap/, internet, diakses pada tanggal 04 April 2018 pukul 14.30 WIB. 
pajaknya. PPAT dapat aktif melaksanakan kewajiban pajak dari wajib pajak, yaitu wajib pajak dapat menitipkan pembayaran BPHTB pada PPAT. Namun dalam praktiknya terdapat transaksi jual beli tanah dan/atau bangunan dimana pembayaran BPHTB-nya dititipkan oleh penerima tanah dan/atau bangunan kepada PPAT. Namun dalam kenyataannya, PPAT yang telah menerima penitipan pembayaran BPHTB tersebut tidak pernah melakukan pembayaran BPHTB ke Negara.

Terdapat berbagai perbuatan pidana atau tindak pidana atau pelanggaran pajak yang dapat dikenakan sanksi pidana. Salah satu contoh pelanggaran pajak yang pernah muncul di media massa dan menimbulkan kerugian keuangan negara adalah kasus manipulasi faktur pajak fiktif. Kasus ini terjadi karena Wajib Pajak terbukti menggunakan dokumen Faktur Pajak tidak sesuai dengan transaksi yang sebenarnya. Salah satu kasusnya terdapat pada kasus PPAT di Semarang yang dikenai tindak pidana Korupsi dan kasus PPAT di Bali dengan tindak pidana Penggelapan BPHTB. Dimana dalam putusan Pengadilan Negeri Semarang Nomor : 156/Pid.Sus-TPK/2015/PN Smg telah diputus melanggar Pasal 3 jo Pasal 18 Undang-Undang Nomor 31 Tahun 1999 jo Pasal 55 ayat (1) ke-1 Kitab Undang-Undang Hukum Pidana (Selanjutnya disebut KUHP) tentang pemberantasan Tindak Pidana Korupsi. Terdakwa diputus dengan putusan 1 (satu) tahun 6 (enam) bulan penjara. Terdakwa dengan sengaja meminta para pihak untuk menitipkan pembayaran BPHTB dan PPh (final), sedangkan terdakwa mengetahui bahwa selaku PPAT bukanlah pejabat atau petugas pemungut pajak, sehingga bertentangan dengan kewajiban hukum terdakwa selaku PPAT. Bahwa uang setoran pajak yang seharusnya terdakwa bayarkan ke kas negara tidak dibayarkan dan melakukan beberapa manipulasi data untuk memperkaya diri sendiri.

Dalam kasus tersebut PPAT melakukan perbuatan melawan hukum dimana terdapat penitipan pembayaran BPHTB yang tidak dibayarkan kepada negara dan digunakan untuk kepentingan pribadi terdakwa. Dimana dalam putusan tersebut diterapkan sanksi tindak pidana korupsi sedangkan disisi lain juga memenuhi sanksi dalam tindak pidana pemalsuan. Dalam kasus tersebut PPAT tidak membayarkan penitipan BPHTB oleh klien kepada kas negara. Berdasarkan Undang-Undang Jabatan Notaris untuk memidanakan Notaris harus berdasarkan aspek formal dari akta Notaris. Namun, jika Notaris terbukti melakukan pelanggaran dari aspek formal, jenis sanksi yang akan 
dikenakan tergantung pada jenis pelanggarannya. ${ }^{5}$ Salah satu jenis pelanggaran yang dilakukan PPAT adalah penyelewengan dana BPHTB.

\section{Tujuan Penelitian}

Penelitian ini bertujuan untuk menganalisis tentang pertanggungjawaban pidana atas penyalahgunaan pembayaran bea perolehan hak atas tanah dan bangunan (BPHTB) oleh pejabat pembuat akta tanah (PPAT).

\section{Manfaat Penelitian}

Dari segi teoritik penelitian ini diharapkan berguna bagi pengembangan hukum Bisnis. Dari segi praktis penelitian ini diharapkan dapat berguna bagi praktik hukum dan penegakan hukum mengenai penanganan kasus atau permasalahan-permasalahan hukum yang berkaitan dengan pertanggungjawaban pidana atas penyalahgunaan pembayaran bea perolehan hak atas tanah dan bangunan (BPHTB) oleh pejabat pembuat akta tanah (PPAT).

\section{Metode Penelitian}

Penelitian ini merupakan penelitian hukum normatif, yaitu penelitian terhadap bahan hukum primer dan bahan hukum sekunder yang terdiri dari peraturan perundangundangan dan regulasi yang berlaku dan berkaitan dengan masalah dalam yang sedang diteliti bertujuan mencari pemecahan atas isu hukum yang timbul didalamnya, sehingga hasil yang dicapai adalah memberikan preskripsi mengenai apa yang seyogyanya atas isu hukum yang diajukan. Pendekatan yang digunakan adalah pendekatan perundangundangan (statute approach), pendekatan konseptual (conceptual approach), dan pendekatan kasus (case approach). ${ }^{6}$ Metode analisis bahan hukum didasarkan pada bahan hukum primer berupa perundangan-undangan dikumpulkan dengan metode inventarisasi dan kategorisasi.

\section{B. PEMBAHASAN}

1. Ratio Decidendi Putusan Pengadilan Terkait Dengan Perkara Penyalahgunaan Pembayaran BPHTB Yang Dilakukan Oleh PPAT

${ }^{5}$ Habib Adjie, Sanksi Perdata dan Administratif Terhadap Notaris Sebagai Pejabat Publik, Refika Aditama, Bandung, 2009, hlm. 120

${ }^{6}$ Peter Mahmud Marzuki, Penelitian Hukum, Kencana Prenada Media Group, Jakarta, 2005, hlm. 113 


\section{a. Pemenuhan Unsur Tindak Pidana Korupsi}

Dasar hukum BPHTB adalah Undang-Undang Nomor 21 Tahun 1997 jo. Undang-Undang Nomor 20 Tahun 2000 Tentang Perubahan atas Undang-Undang Nomor 21 Tahun 1997 Tentang Bea Perolehan Hak atas Tanah dan Bangunan. Hak atas tanah dan atau bangunan adalah hak atas tanah, termasuk Hak Pengelolaan, termasuk bangunan di atasnya, sebagaimana dimaksud dalam Undang-Undang Nomor 5 Tahun 1960 Tentang Peraturan Dasar Pokok-Pokok Agraria (UUPA), Undang-Undang Nomor 16 Tahun 1985 Tentang Rumah Susun, dan ketentuan peraturan perundang-undangan lain yang berlaku. Hal ini berarti BPHTB hanya boleh dikenakan atas perolehan hak yang diatur dalam UUPA, Undang-Undang Rumah Susun, dan Hak Pengelolaan. Perolehan hak-hak atas tanah lain yang berkembang di masyarakat adat tetapi tidak diakui oleh UUPA tidak boleh dikenakan BPHTB. ${ }^{7}$

Dalam kasus tersebut pembayaran BPHTB dan PPh tidak pernah dilakukan oleh PPAT bahkan setelah klien menyerahkan penitipan pembayaran BPHTB dan $\mathrm{PPh}$ final tersebut. PPAT tersebut memiliki itikad tidak baik dengan cara menyuruh seseorang (pemalsu/oknum broker) untuk melakukan pemalsuan surat-surat dan bukti pembayaran BPHTB dan PPh (Final), sementara uang sejumlah Rp. 823.536.000,00 (delapan ratus dua puluh tiga juta lima ratus tiga puluh enam ribu rupiah) yang diberikan oleh wajib pajak yang semestinya di setorkan ke kas negara berada dalam penguasaan pelaku dan tidak pernah dibayarkan.

Dalam proses pembayaran pajak BPHTB terdapat perbuatan yang mengandung sifat melawan hukum yang dilakukan oleh PPAT, yaitu uang setoran pajak PPh Final dan BPHTB sejumlah Rp. 823.536.000,00 (delapan ratus dua puluh tiga juta lima ratus tigapuluh enam ribu rupiah) yang berada dalam kekuasaan PPAT dari para wajib pajak tersebut tidak dibayarkan ke kas negara. PPAT sebagai pejabat yang karena kedudukannya boleh menerima titipan pembayaran tersebut untuk disetor ke kas Negara sebagai pihak ketiga. Pembayaran BPHTB dalam sistem pembayaran pajak di Indonesia menggunakan sistem self assesment dimana wajib pajak diberi kepercayaan untuk menghitung dan membayar sendiri pajak yang

\footnotetext{
${ }^{7}$ Marihot Pahala Siahaan, Op. Cit, hlm. 41.
} 
terutang. Sehingga PPAT dapat menjadi tali penghubung atau pihak ketiga dalam pembayaran BPHTB tersebut. Dalam suatu transaksi jual beli tanah dan atau bangunan, pembeli biasanya karena tidak mau repot, menitipkan pembayaran BPHTB kepada PPAT. PPAT ini diberi kewenangan untuk memeriksa apakah Bea Perolehan Hak Atas Tanah dan Bangunan (BPHTB) terutang sudah disetorkan ke Kas Negara oleh Pihak yang memperoleh hak sebelum pejabat yang berwenang menandatangani dokumen yang berkenaan dengan perolehan dimaksud. Di sinilah peluang bagi PPAT untuk melakukan penggelapan uang yang telah dititipkan wajib pajak kepadanya.

Pertanggungjawaban pidana atas perbuatan tersebut dapat ditujukan pada PPAT, Pemalsu (pensiunan pegawai BPN), dan Karyawan PPAT. Pertanggung jawaban pidana pada dasarnya mengarah pada pemahaman pemidanaan terhadap pelaku tindak pidana. Tindak pidana merupakan perbuatan yang dikenakan hukuman pidana baik pelaku maupun akibat perbuatannya. Pertanggung jawaban pidana adalah suatu bentuk untuk menentukan apakah seorang tersangka atau terdakwa dipertanggungjawabkan atas suatu tindak pidana yang telah terjadi. Menurut Roeslan Saleh pertanggungjawaban pidana diartikan sebagai diteruskannya celaan yang objektif yang ada pada perbuatan pidana dan secara subjektif memenuhi syarat untuk dapt dipidana karena perbuatannya itu. ${ }^{8}$

Dalam hukum pidana, ukuran yang menentukan seseorang dapat mempertanggungjawabkan perbuatannya secara pidana dilihat dari kemampuan bertanggungjawab orang tersebut. Unsur kesalahan merupakan unsur utama dalam pertanggungjawaban pidana. Terdakwa Damar telah memenuhi unsur kesalahan maka dari padanya dapat dimintai pertanggungjawaban pidana atas apa yang telah diperbuat. Pertanggungjawaban pidana mengandung makna bahwa setiap orang yang melakukan tindak pidana atau melawan hukum, sebagaimana dirumuskan dalam undang-undang, maka orang tersebut patut mempertanggungjawabkan perbuatan sesuai dengan kesalahannya. Pertanggungjawaban dalam hukum pidana menganut asas tiada pidana tanpa kesalahan (geen straf zonder schuld). Tidak dapat

\footnotetext{
${ }^{8}$ Roeslan saleh, Pikiran-Pikiran Tentang Pertanggung Jawaban Pidana, Ghalia Indonesia, Jakarta,
} 1986, hlm. 33 
dipisahkan antar kesalahan dan pertanggungjawaban atas perbuatan. ${ }^{9}$ Berkaitan dengan pertanggungjawaban pidana, terdapat beberapa hal yang harus diperhatikan, yaitu $:^{10}$

1) Unsur kesalahan

a) melakukan tindak pidana;

b) diatas umur tertentu dan mampu bertanggungjawab;

c) kesengajaan atau kealpaan;

d) tidak ada alasan pemaaf.

2) Bentuk atau corak kesalahan

a) Dengan kesengajaan;

b) Dengan kealpaan.

Dalam hal penitipan uang pajak, PPAT berwenang dan boleh menerima titipan pajak PPh Final dan pajak BPHTB sesuai tugasnya sebagai PPAT yang menyelesaikan akta-akta peralihan hak atas tanah. Dimana dalam pelaksanaannya berdasarkan atas kepercayaan menurut hukum kebiasaan yang berlaku terus menerus dan diakui serta diterima masyarakat dan berlaku dalam praktik, serta telah diterima dalam birokrasi pengurusan hak-hak atas tanah dan peralihannya. Oleh karena itu, maka dapat dibenarkan jika PPAT menerima titipan pajak BPHTB yang langsung berhubungan dengan tugasnya.

Proses peralihan hak atas jual beli tanah dan bangunan di Jalan Siliwangi 440 Kalibanteng Kulon Semarang telah disalahgunakan oleh PPAT, dimana terjadinya Tindak Pidana Penyelewengan uang pajak pada proses peralihan hak atas jual beli tanah dan bangunan tersebut, yaitu dengan cara memalsukan dokumen surat setoran bea (SSB) di bank BPD Jateng dan surat setoran pajak (SSP) di bank BTN Cab. Semarang seakan-akan sudah terjadi Pembayaran Pajak BPHTB setoran SSB \& SSP sebesar Rp 411.768.000,00 (empat ratus sebelas juta tujuh ratus enam puluh delapan rupiah). Jika ditinjau dari unsur korupsi dalam tuntutan maupun putusan dalam perkara Nomor: 156/Pid.Sus-TPK/2015/PN Smg maka terdakwa masuk dalam lingkup tindak pidana korupsi, dimana tindak pidana korupsi merupakan tindak pidana khusus. Tindak pidana khusus adalah tindak pidana yang diatur tersendiri dalam undang-undang khusus, yang memberikan peraturan khusus cara

\footnotetext{
${ }^{9}$ Adami Chazawi, Pelajaran Hukum Pidana 1, Rajagrafindo Persada, Jakarta, 2007, hlm. 151

${ }^{10}$ Didik Endro Purwoleksono, Hukum Pidana, Airlangga University Press, Surabaya, 2013, hlm. 63
} 
penyidikannya, tuntutannya, pemeriksaannya maupun sanksinya menyimpang dari ketentuan yang dimuat dalam KUHP yang lazimnya lebih ketat dan lebih berat. ${ }^{11}$

BPHTB merupakan kewajiban dari pihak yang memperoleh hak atas tanah dan/atau bangunan, bukan merupakan kewajiban daripada PPAT, sebagaimana yang dicantumkan pada Pasal 1 angka 45 Undang-Undang Nomor 28 Tahun 2009 Tentang Pajak Daerah dan Retribusi Daerah yang berisi "wajib pajak adalah seorang pribadi atau badan, meliputi pembayar pajak, pemotong pajak, dan pemungut pajak, yang mempunyai hak dan kewajiban perpajakan sesuai dengan ketentuan peraturan perundang-undangan perpajakan daerah. Dengan digunakannya sistem self assesment di Indonesia maka wajib pajak dapat menghitung dan membayar sendiri pajak terutang. Dengan menghitung dan membayar sendiri Pajak terutang tersebut, disinilah sisi daripada PPAT untuk dapat membantu Wajib Pajak sebagai pihak ketiga. PPAT menerima titipan pajak BPHTB dan PPh yang langsung berhubungan dengan tugasnya hal tersebut dapat masuk pada ranah tindak pidana korupsi, hal tersebut dapat terjadi apabila telah dilakukan pembuatan akta jual beli (AJB), karena uang pajak PPh Final dan pajak BPHTB sejak diserahkan/dipotong oleh notaris / PPAT dan berada dalam kekuasannya telah berubah sifat menjadi uang Negara.

\section{b. Beralihnya Uang Pajak Menjadi Uang Negara}

Kewajiban pajak merupakan kewajiban publik yang pribadi dan hal tersebut tidak dapat dialihkan kepada orang lain. Namun dalam hal sistem pemungutan pajak yang menggunakan sistem self assesment maka pajak dapat dikuasakan, oleh karena itu wajib pajak dapat meminta bantuan atau memberi kuasa kepada orang lain akan tetapi kewajiban tetap melekat pada dirinya dan wajib pajak berhak bertanggungjawab walaupun orang lain yang ditunjuk olehnya dapat ikut mempertanggungjawabkan. Subjek pajak BPHTB dan PPh Final menjadi wajib pajak ketika ada kegiatan jual beli tanah dimana untuk terjadinya peralihan hak, maka para penjual dan pembeli diwajibkan membayar pajak.

Pembayaran uang pajak secara langsung masuk kedalam kas negara dan dipergunakan semata-mata untuk kesejahteraan masyarakat, kepentingan umum,

\footnotetext{
${ }^{11}$ Rochmat Soemitro, Asas dan Dasar Perpajakan 3, Eresco, Bandung, 1990, hlm. 18.
} 
pembangunan, dan lain-lain berkaitan dengan penyelenggaraan negara. Dalam hal terjadinya jual beli ada pajak yang harus dibayarkan yaitu pembayaran pajak BPHTB dan PPh. Dalam kasus PPAT Damar yaitu telah melakukan penggelapan pajak BPHTB sehingga dijerat dengan undang-undang tindak pidana korupsi. Sifat uang Negara menjadi melekat / timbul sejak wajib pajak yang in casu pihak wajib pajak mempercayakan dan menyerahkan uang itu pada PPAT dan diterima oleh PPAT Damar, dimana terdakwa Damar adalah pejabat yang karena kedudukannya sebagai PPAT boleh menerima titipan uang untuk disetor ke Kas Negara. Secara hukum uang setoran pajak (BPHTB dan PPh Final) sejumlah Rp.823.536.000,00 yang berada dalam penguasaan pelaku, sudah menjadi uang negara sejak terjadinya peralihan hak atas tanah dan dibuatnya akta jual beli, oleh karena itu adalah hak negara untuk menerima uang tersebut walaupun sudah berada pada kekuasaan terdakwa. Sehingga Pelaku sebagai pejabat yang dititipkan berkewajiban (diharuskan) untuk menyetorkan uang tersebut ke kas negara. Dengan tidak dibayarkannya kepada kas negara maka terdakwa telah secara nyata melakukan perbuatan melawan hukum yang menimbulkan kerugian pada keuangan negara. Maka terdakwa dapat dituntut telah melakukan tindak pidana dan dijerat dengan pasal dalam undang-undang tindak pidana korupsi.

Dalam sebab lain, jika akta jual beli dikatakan telah masuk ke dalam uang negara itu dikarenakan konteks terjadinya peralihan hak itu adanya pembayaran pajak oleh wajib pajak yang masuk menjadi uang negara, dalam kasus terdakwa Damar ini, PPAT Damar memalsukan dokumen pembayaran pajak dalam pembuatan akta jual belinya sehingga tervalidasi dan terbitnya sertifikat, akibatnya uang pajak tidak masuk dalam kas negara sehingga hal tersebut dapat merugikan negara. Dari sinilah dapat disimpulkan mengapa kasus PPAT Damar ini masuk dalam ranah tindak pidana khusus yaitu tindak pidana korupsi. Hal ini bukan lagi merupakan kesalahan wajib pajak, tetapi kesalahan murni dari PPAT Damar, karena wajib pajak telah memenuhi semua persyaratan namun penyalur wajib pajak yaitu PPAT Damar yang telah merugikan negara.

\section{c. Kewenangan Pembayaran BPHTB Yang Dilakukan Oleh PPAT}


Fungsi pajak merupakan upaya bagi negara untuk meningkatkan pendapatan, karena pajak adalah salah satu sumber pendapatan penting bagi negara. Dalam hal ini pajak terlihat hanya mempunyai fungsi sebagai sumber keuangan negara (Budgetair atau Fungsi Finansial) dalam hal ini pajak juga fungsi Mengatur (Regulerend).Kewenangan pemungutan dan pengelolaan dari BPHTB berdasarkan pada Undang-Undang tentang Pajak Daerah dan Retribusi Daerah yang lama merupakan kewenangan Pemerintah Pusat untuk memungut dan mengelolanya. Namun pada saat ini, BPHTB merupakan bagian dari kewenangan pemerintah daerah. Hal ini diwujudkan melalui ketentuan dalam Undang-undang Nomor 28 Tahun 2009 tentang Pajak Daerah dan Retribusi Daerah yang ditetapkan pada tanggal 15 September 2009 dan mulai berlaku pada tanggal 1 Januari 2010. ${ }^{12}$

Tujuan dari pada pengalihan BPHTB menjadi pajak daerah adalah untuk memberikan kewenangan yang lebih besar kepada daerah dalam meningkatkan Pendapatan Asli Daerah (PAD). Belum adanya Perda tentang Pajak Daerah dan Retribusi Daerah di suatu daerah kabupaten/kota, mengakibatkan pemungutan dan pengelolaannya masih tetap sama, yakni menggunakan ketentuan perpajakan daerah dan retribusi daerah yang lama yaitu Undang-Undang Nomor 18 Tahun 1997 sebagaimana telah dirubah dengan Undang-Undang Nomor 34 Tahun 2000, sehingga dikembalikan bagi pengelolaannya kepada pemerintah pusat. Pemungutan pajak daerah saat ini menggunakan tiga sistem pemungutan pajak, yaitu sebagai berikut $:^{13}$

1) Dibayar sendiri oleh wajib pajak. sistem ini merupakan perwujudan dari sistem self assesment, yaitu sistem pengenaan pajak yang memberi kepercayaan kepada wajib pajak untuk menghitung, membayar dan melaporkan sendiri pajak yang terutang dengan menggunakan SPTPD.

2) Ditetapkan oleh kepala daerah. Sistem ini merupakan perwujudan dari sistem official assesment, yaitu sistem pengenaan pajak yang dibayar oleh wajib pajak setelah terlebih dahulu ditetapkan oleh kepala daerah atau pejabat yang ditunjuk melalui Surat Ketetapan Pajak Daerah atau Dokumen lain yang dipersamakan.

${ }^{12}$ Marihot Pahala Siahaan, Bea Perolehan Hak Atas Tanah dan Bangunan (BPHTB) Sebagai Pajak Daerah, Sagung Seto, Jakarta, 2011, , hlm. 21. 2010, hlm. 99

13 Marihot Pahala Siahaan, Pajak Daerah dan Retribusi Daerah, Raja Grafindo Persada, Jakarta, 
3) Dipungut oleh pemungut pajak. sistem ini merupakan perwujudan dari sistem with holding, yaitu sistem pengenaan pajak yang dipungut oleh pemungut pajak pada sumbernya, antara lain Perusahaan Listrik Negara (PLN) yang telah ditetapkan berdasarkan Peraturan Pemerintah Nomor 65 Tahun 2001 tentang Pajak Daerah, sebagai pemungut pajak penerangan jalan atas penggunaan tenaga listrik yang disediakan PLN.

Tata cara pemungutan pajak berdasarkan Undang-Undang Nomor 28 Tahun 2009 tentang Pajak Daerah dan Retribusi Daerah menganut sistem Self Assesment dan Official Assesment, hal tersebut tertuang dalam Pasal 96 ayat (2) yang mengatur bahwa setiap Wajib Pajak wajib membayar pajak yang terutang berdasarkan surat ketetapan pajak atau dibayar sendiri oleh wajib pajak berdasarkan peraturan perundang - undangan perpajakan. Official Assesment pemungutan pajak ini tampak dalam ketentuan Pasal 96 ayat (3) jo. ayat (4) yang mengatur bahwa Wajib Pajak yang memenuhi kewajiban perpajakan berdasarkan penetapan Kepala Daerah dibayar dengan menggunakan Surat Ketetapan Pajak Daerah (SKPD) atau dokumen lain yang dipersamakan berupa karcis dan nota perhitungan. Sedangkan sistem Self Assesment tampak dalam ketentuan Pasal 96 ayat (5) yang mengatur bahwa Wajib Pajak yang memenuhi kewajiban perpajakan sendiri dibayar dengan menggunakan Surat Pemberitahuan Pajak Daerah (SPPD), Surat Ketetapan Pajak Daerah Kurang Bayar (SKPDKB), dan/atau Surat Ketetapan Pajak Daerah Kurang Bayar Tambahan (SKPDKBT). ${ }^{14}$

Sistem pemungutan BPHTB menganut sistem self assesment dimana wajib pajak diberi kepercayaan untuk menghitung dan membayar sendiri pajak yang terutang. Hal tersebut sebagaimana diatur dalam Peraturan Pemerintah Nomor 91 Tahun 2010 tentang Jenis Pajak Daerah Yang Dipungut Berdasarkan Penetapan Kepala Daerah Atau Dibayar Sendiri Oleh Wajib Pajak dimana ditentukan dalam Pasal 4 bahwa Bea Perolehan Hak atas Tanah dan Bangunan (BPHTB) merupakan jenis pajak yang dibayar sendiri oleh Wajib Pajak. Oleh karena itu Wajib Pajak dalam melakukan pembayaran BPHTB menghitung sendiri pajak terutangnya.

${ }^{14}$ Nomi Chairaini Tarigan, “Analisis Yuridis Atas Pelayanan Notaris/Ppat Kepada Kliennya Dalam Hal Pembayaran Pajak Penghasilan (PPh) Dan Bea Perolehan Hak Atas Tanah Dan Bangunan (BPHTB) (Studi Di Kota Medan)", Tesis, Magister Kenotariatan Universitas Sumatera Utara, Medan, 2017, hlm. 44. 
Dalam pembayaran BPHTB dan PPh, terjadi proses jual beli tanah dimana pembeli dan penjual telah sepakat untuk mengadakan perjanjian jual beli atas sebidang tanah dan telah menentukan waktu untuk melaksanakan proses jual beli tersebut dengan melaksanakan akta jual beli di hadapan PPAT pada waktu yang telah ditentukan. Pembayaran atas harga tanah akan dilakukan pada waktu pelaksanaan akta jual beli. Untuk melaksanakan akta jual beli tersebut, PPAT telah meminta dokumen-dokumen yang diperlukan agar diserahkan kepada PPAT. Dalam ketentuan Pasal 20 tahun 2000 tentang BPHTB pada Pasal 24 (1) yaitu menyatakan bahwa PPAT/Notaris hanya dapat menandatangani Akta Pemindahan Hak atas Tanah dan atau Bangunan setelah wajib pajak menyerahkan Bukti Pembayaran Pajak, dengan kata lain dengan adanya penitipan pembayaran BPHTB dan PPh yang seharusnya dibayarkan oleh wajib pajak, namun dititipkan dan dibayarkan oleh PPAT apabila telah dilakukan pembayaran maka PPAT dapat memberikan bukti pelunasan atas pembayaran BPHTB dan PPh tersebut. Dengan adanya bukti pelunasan tersebut maka proses akta jual beli dan balik nama dapat dilaksanakan.

\section{Peran PPAT Dalam Pembayaran BPHTB}

Berdasarkan Pasal 1 ayat (1) Peraturan Pemerintah Nomor 37 Tahun 1998 Tentang Peraturan Jabatan Pejabat Pembuat Akta Tanah (Diundangkan dalam Lembaran Negara Tahun 1998 Nomor 52, Tambahan Lembaran Negara Nomor 3746) menyebutkan bahwa PPAT adalah Pejabat Umum yang diberi kewenangan untuk membuat akta-akta otentik mengenai perbuatan hukum tertentu mengenai hak atas tanah atau hak milik atas satuan rumah susun. Tugas dari PPAT adalah sebagai berikut: ${ }^{15}$

a. Membuat akta mengenai perbuatan hukum yang berhubungan dengan hak atas tanah dan hak tanggungan,

b. Membantu pihak-pihak yang melakukan perbuatan hukum untuk mengajukan permohonan ijin pemindahan hak dan permohonan pengawasan konversi serta pendaftaran hak atas tanah.

Saat pajak terutang yaitu pada saat tanggal dibuat dan ditandatanganinya akta, karena sebagian besar yang berkaitan dengan hak atas tanah dan/bangunan yang terjadi hlm. 52 .

${ }^{15}$ Edi Ruchiyat, Sistem Pendaftaran Tanah Sebelum dan Sesudah UUPA, Amico, Bandung, 1989. 
berkaitan dengan dibuktikan dengan adanya akta autentik. BPHTB merupakan kewajiban dari pihak yang memperoleh hak atas tanah dan/atau bangunan, bukan merupakan kewajiban daripada PPAT, sebagaimana yang dicantumkan pada Pasal 1 angka 45 Undang-Undang Nomor 28 Tahun 2009 Tentang Pajak Daerah dan Retribusi Daerah yang berisi "wajib pajak adalah seorang pribadi atau badan, meliputi pembayar pajak, pemotong pajak, dan pemungut pajak, yang mempunyai hak dan kewajiban perpajakan sesuai dengan ketentuan peraturan perundang-undangan perpajakan daerah. Dengan digunakannya sistem self assesment di Indonesia maka wajib pajak dapat menghitung dan membayar sendiri pajak terutang. Dengan menghitung dan membayar sendiri Pajak terutang tersebut, disinilah sisi daripada PPAT untuk dapat membantu Wajib Pajak sebagai pihak ketiga. Wajib Pajak dapat menitipkan pembayaran BPHTB kepada PPAT. Didalam perkembangan sekarang ini, terkadang seseorang sudah sedemikian sibuknya dengan berbagai kepentingan sehingga seringkali untuk menyelesaikan kepentingan-kepentingan tersebut, ia tidak dapat hadir sendiri secara fisik. Oleh karena itu ia memerlukan jasa orang lain didalam menyelesaikan kepentingannya tersebut. Disini Wajib Pajak dapat menggunakan surat kuasa untuk menunjuk PPAT sebagai pihak ketiga yang melakukan penghitungan dan pembayaran BPHTB.

Pasal 24 ayat (I) Undang-Undang Nomor 21 Tahun 1997 tentang BPHTB” dinyatakan bahwa PPAT hanya dapat menandatangani akta pemindahan hak atas tanah dan/atau bangunan setelah wajib pajak menyerahkan bukti pembayaran pajak, berupa Surat Setoran Pajak (SSP) dari Pihak Penjual dan Surat Setoran Bea Perolehan Hak Atas Tanah dan Bangunan (SSB) dari Pihak Pembeli. Peranan PPAT dalam transaksi peralihan hak atas tanah dan bangunan adalah diikutsertakan untuk melakukan pengawasan atas pembayaran pajak-pajak yang terutang pada pengalihan hak atas tanah dan bangunan dengan cara hanya boleh menandatangani akta pengalihan hak atas tanah dan bangunan jika pajaknya sudah dibayar. Hal tersebut telah diatur dalam pasal 91 ayat (1) Undang-Undang Nomor 28 Tahun 2009 tentang Pajak Daersah dan Retribusi Daerah. Jika hal ini tidak dilaksanakan maka PPAT yang membuat Akta Jual Beli (AJB) dikenakan sanksi berdasarkan Pasal 93 ayat (1) Undang-Undang Nomor 28 Tahun 2009 tentang Pajak Daerah Dan Retribusi Daerah. 
Dalam proses administrasi penandatanganan sebuah akta oleh Pejabat Pembuat Akta Tanah (PPAT), PPAT mewajibkan kepada Wajib Pajak (WP) untuk menyerahkan bukti pembayaran atau pelunasan pajak BPHTB yang terhutang melalui form Surat Setoran Pajak Daerah Bea Perolehan Hak atas Tanah dan Bangunan (SSPD BPHTB) dan telah tervalidasi oleh pihak Kantor Dinas Pendapatan Daerah serta Pajak Penghasilan (PPh) Final atas peralihan hak atas tanah dan bangunan. Bilamana dalam proses administrasi di atas terdapat sebuah berkas yang dapat lolos dan telah masuk serta didaftarkan di Badan Pertanahan Nasional (BPN) maka Kepala Kantor Dinas Pendapatan Daerah juga akan meminta bukti pelunasan atau pembayaran tersebut kepada Wajib Pajak sebelum didaftarkan sertipikat tanah tersebut. Bukti pelunasan atau pembayaran itu sendiri juga harus telah ditandatangani dan divalidasi oleh pihak Kantor Dinas Pendapatan Daerah (khusus untuk BPHTB), sedang untuk PPh Final telah diprint out oleh pihak bank penerima dana setoran pajak tersebut. ${ }^{16}$

Fungsi PPAT adalah menjamin kebenaran materiil dan kebenaran formil dalam setiap akta peralihan hak atas tanah dan bangunan serta berperan juga untuk memeriksa kewajiban-kewajiban para pihak yang harus dipenuhi berkaitan dengan peralihan hak tersebut. Oleh karena itu dalam praktiknya sehari-hari PPAT diwajibkan untuk senantiasa menjungjung tinggi hukum dan asas negara serta bertindak sesuai dengan makna sumpah jabatan dan mengutamakan pengabdiannya kepada kepentingan negara dan masyarakat. Kode etik dalam menjalankan jabatan hanya sebagai pagar pengingat terhadap PPAT pada apa yang boleh dan tidak boleh. Sedangkan jika PPAT tersebut berperilaku menyimpang dari suatu aturan hukum pidana dalam masyarakat, maka PPAT tersebut akan dijerat dengan undang-undang hukum pidana beserta sanksi pidananya.

\section{b. Keabsahan akta jual beli Terkait Faktur Pajak BPHTB Dan PPh Final Dipalsukan}

Tanah dan bangunan adalah benda tidak bergerak (benda tetap) sehingga proses jual belinya berbeda dengan jual beli benda bergerak seperti kendaraan, televisi, dan lain-lain. Secara hukum, jual beli benda bergerak terjadi secara tunai dan seketika, yaitu selesai ketika pembeli membayar harganya dan penjual menyerahkan barangnya.

\footnotetext{
${ }^{16}$ Nomi Chairaini Tarigan, Op.Cit., hlm. 69.
} 
Namun berbeda dengan proses jual beli tanah dan bangunan, dimana jual beli tersebut memerlukan akta otentik yang dibuat oleh pejabat umum yaitu PPAT. Menurut Pasal 1874 BW, Akta ialah suatu salinan yanq memang dengan sengaja dibuat untuk dijadikan bukti tentang suatu peristiwa dan ditandatangani. Dengan demikian, unsurunsur penting untuk suatu akta, ialah kesengajaan untuk menciptakan suatu bukti tertulis dan penandatanganan tertu 1 is. ${ }^{17}$

Menurut ketentuan Pasal 1870 BW, yaitu tentang kekuatan dan akta otentik sebagai alat pembuktian adalah suatu akta otentik memberikan di antara pihak beserta ahli warisnya atau orang-orang yang mendapat hak dan pada mereka, suatu bukti yang sempurna tentang apa yang dimuat didalamnya. Akta otentik mempunyai kekuatan pembuktian yang mutlak. Apabila dikemudian hari timbul suatu sengketa, maka akta otentik dapat dijadikan sebagai alat bukti yang sempurna sehingga pembuktiannya juga dapat tanpa alat bukti yang lainnya. Hal ini berbeda dengan akta dibawah tangan, dimana akta dibawah tangan kekuatan pembuktiannya belum sempurna apabila masih disangkal oleh salah satu pihak, dan menjadi sempurna apabila sudah diakui oleh kedua belah pihak.

Terhadap jual beli tanah, tanpa adanya akta otentik dari PPAT maka jual beli tanah tersebut tidak menyebabkan beralihnya tanah dan bangunan. Untuk dapat beralihnya suatu objek yaitu tanah dan bangunan maka harus dilakukan dengan akta jual beli atau AJB. Akta jual beli merupakan syarat untuk pencatatan balik nama sertifikat tanah dari penjual kepada pembeli. Akta jual beli tanah adalah akta otentik yang dibuat oleh PPAT dimana memiliki fungsi antara lain yaitu adanya bukti berupa suatu akta PPAT yang merupakan syarat bagi pendaftaran jual belinya oleh Kepala Kantor Pertanahan, bahwa benar telah dilakukan perbuatan hukum dan membuktikan adanya perpindahan hak atas tanah kepada penerima hak baru. Pemindahan haknya hanya dapat didaftarkan jika dibuktikan dengan akta PPAT. Demikian ditentukan dalam Pasal 37 ayat (1) PP No 24 tahun 1997 yang menyatakan :

"Peralihan hak atas tanah dan hak milik atas satuan rumah susun melalui jual beli, tukar menukar, hibah, pemasukan dalam perusahaan dan perbuatan hukum pemindahan hak lainnya, kecuali pemindahan hak melalui lelang, hanya dapat didaftarkan, jika dibuktikan dengan akta yang dibuat oleh PPAT

\footnotetext{
${ }^{17}$ R. Subekti, Hukum Pembuktian, Pradnya Paramita, Jakarta, 1979, hlm. 23.
} 
yang berwenang menurut ketentuan peraturan perundang-undangan yang berlaku."

Dalam pembuatan akta jual beli, masing-masing pihak penjual dan pembeli berkewajiban membayar pajak transaksi. Penjual wajib membayar Pajak Pertambahan Nilai (PPN) sebesar 5\% dan pembeli wajib membayar Bea Perolehan Hak atas Tanah dan Bangunan (BPHTB) sebesar 5\%. Setelah pembuatan akta jual beli dan pembayaran pajak, maka PPAT akan melakukan balik nama sertifikat di kantor pertanahan dan setelah itu tanah dan bangunan telah sah menjadi milik pembeli.

Dalam hal terjadinya pembuatan akta jual beli pada kasus PPAT Damar, terdakwa telah memalsukan beberapa dokumen pembayaran pajak sehingga dapat tervalidasi sampai dengan diterbitkannya sertifikat tersebut. Dalam artian adalah bahwa jual beli telah berlangsung seolah-olah secara sah telah terjadi, padahal dibalik itu semua proses penyelesaian peralihan hak tersebut menuai suatu sebab yang tidak halal, pemalsuan dan terlarang. Dari berbagai hal tipu muslihat tersebut akibatnya adalah akta jual beli menjadi batal demi hukum. Tata cara terbitnya akta PPAT sebagai akta otentik sangatlah menentukan, karenanya apabila pihak yang berkepentingan dapat membuktikan adanya cacat dalam bentuknya karena adanya kesalahan atau ketidaksesuaian dalam tata cara pembuatannya maka akan mengakibatkan timbulnya risiko bagi kepastian hak yang timbul atau tercatat atas dasar akta tersebut. Sedangkan dalam kasus tersebut sebelum adanya akta jual beli segala prosesnya telah dipalsukan. Maka Terdakwa Damar telah melakukan pemalsuan surat. Dalam hal ini yang dapat dilakukan oleh klien terdakwa atau wajib pajak selain dituntut secara pidana maka dapat menggugat terdakwa secara perdata atas wanprestasi yang dilakukan oleh terdakwa.

Konsekuensi atas akta jual beli yang telah dibuat terdakwa yaitu sah dalam hal dalam pegangan penjual dan pembeli. Namun dimata negara akan menjadi tidak sah oleh karena nya segala proses terjadinya akta jual beli tersebut tidak benar. Ada dua konsekuensi yang dapat berlaku apabila syarat sah suatu akta tersebut tidak terpenuhi yaitu: ${ }^{18}$

${ }^{18}$ Munir Fuady, Hukum Perjanjian, Dari Sudut Pandang Hukum Bisnis Cet 2, Citra Aditya Bakti, Bandung, 2001, hlm. 34. 
a. Batal demi hukum yaitu tidak terpenuhinya syarat objektif (Pasal $1320 \mathrm{BW}$ ) Syarat objektif tersebut adalah:

1) Perihal tertentu, dan

2) Sesuatu yang halal.

b. Dapat dibatalkan yaitu tidak terpenuhinya syarat subjektif (Pasal $1320 \mathrm{BW}$ ) Syarat subjektif adalah :

1) Sepakat;

2) Cakap.

Dari kedua konsekuensi tersebut maka akta jual beli tersebut batal demi hukum, oleh karenanya akta tersebut dibuat karena suatu sebab yang palsu atau terlarang adalah tidak mempunyai kekuatan hukum. batal demi hukum mengandung pengertian bahwa akibat-akibat dari keputusan dianggap tidak pernah ada atau dikembalikan seperti semula sebelum adanya keputusan. tidak terpenuhinya (salah satu) syarat objektif dapat mengakibatkan perjanjian tersebut batal demi hukum, artinya sejak semula dianggap tidak pernah dilahirkan suatu perjanjian dan tidak pernah ada suatu perjanjian. Apabila para pihak merasa dirugikan maka para pihak dapat membuat kembali akta jual beli tersebut dan atas persetujuan serta kesepakatan kedua belah pihak. Terdakwa Damar wajib membayar uang penitipan BPHTB dan PPh (final) yang klien terdakwa titip agar pemenuhan syarat pembayaran pajak tersebut lunas serta proses balik namapun dapat dilakukan dan sah di muka hukum.

\section{PENUTUP}

\section{Kesimpulan}

Berdasarkan hasil penelitian dan pembahsan diatas, maka penulis menarik kesimpulan sebagai berikut:

a. Ratio decidendi pada putusan Nomor 156/Pid.Sus-TPK/2015/PN Smg memutus Terdakwa secara sah dan meyakinkan terbukti bersalah melakukan tindak pidana dalam Dakwaan Subsidiair, yaitu melanggar Pasal 3 Jo Pasal 18 Undang Undang Nomor 31 Tahun 1999 Jo Pasal 55 (1) Ke 1 KUHP Tentang Pemberantasan Tindak Pidana Korupsi Sebagaimana Diubah dengan Undang Undang Nomor 20 Tahun 2001 Tentang Perubahan Atas Undang Undang Nomor 31 Tahun 1999 Tentang Pemberantasan Tindak Pidana Korupsi. Sifat uang Negara menjadi melekat / timbul sejak wajib pajak yang in casu, pihak wajib pajak mempercayakan dan menyerahkan uang itu pada PPAT dan diterima oleh PPAT Damar, dimana terdakwa Damar adalah 
pejabat yang karena kedudukannya sebagai PPAT boleh menerima titipan uang untuk disetor ke Kas Negara.

b. Keabsahan akta jual beli terkait faktur pajak BPHTB dan PPh (final) yang dipalsukan adalah batal demi hukum, oleh karenanya akta tersebut dibuat karena suatu sebab yang palsu atau terlarang adalah tidak mempunyai kekuatan hukum. Batal demi hukum mengandung pengertian bahwa akibat-akibat dari keputusan dianggap tidak pernah ada atau dikembalikan seperti semula sebelum adanya keputusan. Tidak terpenuhinya (salah satu) syarat objektif dapat mengakibatkan perjanjian tersebut batal demi hukum, artinya sejak semula dianggap tidak pernah dilahirkan suatu perjanjian dan tidak pernah ada suatu perjanjian.

\section{Saran}

Berdasarkan pada Ratio decidendi pada putusan Nomor 156/Pid.SusTPK/2015/PN Smg dan Keabsahan akta jual beli terkait faktur pajak BPHTB dan PPh (final) yang dipalsukan adalah batal demi hukum. Maka Pemerintah pusat perlu membuat peraturan yang mengatur tentang pembatasan dan, prosedur pihak wajib pajak mempercayakan dan menyerahkan uang itu pada PPAT dan diterima oleh PPAT.

\section{DAFTAR PUSTAKA}

\section{$\underline{\text { Buku }}$}

Adjie Habib, Sanksi Perdata dan Administratif Terhadap Notaris Sebagai Pejabat Publik, Refika Aditama, Bandung, 2009;

Chazawi Adami, Pelajaran Hukum Pidana 1, Rajagrafindo Persada, Jakarta, 2007;

Fuady Munir, Hukum Perjanjian, Dari Sudut Pandang Hukum Bisnis Cet 2, Citra Aditya Bakti, Bandung, 2001.

Ilyas Wirawan B., dan Ricard Burton, Hukum Pajak, Edisi Revisi, Salemba Empat, Jakarta, 2004;

Marzuki Peter Mahmud, Penelitian Hukum, Prenadamedia Group, Surabaya, 2005; 
; Penelitian Hukum, Yuridika, Vol. 16, No. 2, Maret 2001;

Purwoleksono Didik Endro, Hukum Pidana, Airlangga University Press, Surabaya, 2013;

R. Subekti, Hukum Pembuktian, Pradnya Paramita, Jakarta, 1979;

Ruchiyat Edi, Sistem Pendaftaran Tanah Sebelum dan Sesudah UUPA, Amico, Bandung, 1989

Saleh Roeslan, Pikiran-Pikiran Tentang Pertanggung Jawaban Pidana, Ghalia Indonesia, Jakarta, 1986;

Siahaan Marihot Pahala, Bea Perolehan Hak Atas Tanah dan Bangunan Teori dan Praktek, Raja Grafindo, Jakarta, 2003;

Siahaan Marihot Pahala, Bea Perolehan Hak Atas Tanah dan Bangunan (BPHTB) Sebagai Pajak Daerah, Sagung Seto, Jakarta, 2011;

: Pajak Daerah dan Retribusi Daerah, Raja Grafindo Persada, Jakarta, 2010;

Soemitro Rochmat, Asas dan Dasar Perpajakan 3, PT Eresco, Bandung, 1990;

; Asas dan Dasar Perpajakan I, Edisi revisi, Refika Aditama, Bandung, 2004.

Tesis

Nomi Chairaini Tarigan, "Analisis Yuridis Atas Pelayanan Notaris/PPAT Kepada Kliennya Dalam Hal Pembayaran Pajak Penghasilan (PPh) Dan Bea Perolehan Hak Atas Tanah Dan Bangunan (BPHTB) (Studi Di Kota Medan)", Tesis, Magister Kenotariatan Universitas Sumatera Utara, Medan, 2017.

\section{Internet}

http://www.akuntansilengkap.com/pajak/3-sistem-pemungutan-pajak-lengkap/, diakses pada tanggal 04 April 2018 pukul 14.30 WIB. 